\title{
Population ecology of the marine insect Halocladius variabilis (Diptera: Chironomidae) in the rocky intertidal zone of Nova Scotia, Canada
}

\author{
D. J. Garbary"***, M. M. Jamieson*, B. R. Taylor*
}

Department of Biology, St. Francis Xavier University, PO Box 5000, 1 West Street, Antigonish, Nova Scotia B2G 2W5, Canada

\begin{abstract}
We studied the population ecology and productivity of the little-known marine insect Halocladius variabilis (Chironomidae) from the exposed rocky intertidal zone on the Atlantic coast of Nova Scotia, Canada. Larvae of $H$. variabilis are host-specific symbionts of the brown alga Elachista fucicola, which in turn is an abundant epiphyte on the dominant intertidal fucoid Ascophyllum nodosum. At our primary study site at Drum Head, A. nodosum frond density (mean \pm SE) was $546 \pm$ 46 fronds $\mathrm{m}^{-2}$ for fronds $>20 \mathrm{~cm}$ long. Density of $E$. fucicola on A. nodosum was highly variable seasonally, with median densities of $20000 \mathrm{~m}^{-2}$ in July. Mean number of $H$. variabilis larvae per E. fucicola thallus varied from $0.8 \pm 0.1$ in November to $3.9 \pm 0.3$ in mid-July. Median density of larvae per frond of $A$. nodosum ranged from 0 in November to 246 in July. The latter number represents a median density of 59500 larvae $\mathrm{m}^{-2}$, making $H$. variabilis one of the most abundant marine insects known. Based on distributions of larval size, $H$. variabilis appears to be univoltine or possibly bivoltine. H. variabilis larvae were largest (6.48 $\pm 0.17 \mathrm{~mm}$ long) in May and smallest in late August $(\sim 2 \mathrm{~mm})$, suggesting a mid-summer period of adult egg-laying. Larval production was conservatively estimated at $130 \mathrm{~g} \mathrm{~m}^{-2} \mathrm{yr}^{-1}$, making this also the most productive chironomid known from any habitat. The high population density and production suggest that $H$. variabilis is an important, but overlooked, component of marine rocky shores of the northwestern Atlantic.
\end{abstract}

KEY WORDS: Chironomidae · Halocladius variabilis · Production · Life cycle • Ascophyllum nodosum $\cdot$ Marine insects

\section{INTRODUCTION}

Despite their evolutionary success on land and in freshwater, relatively few insects have invaded the intertidal zone of the marine environment (Cheng 1976). An exception to this generalization is the family Chironomidae (order Diptera), which includes taxa restricted to marine environments (Colbo 1996) and several intertidal species. Specialized species of chironomids (non-biting midges) are known from the open ocean, coastal brackish waters, tide pools, estuaries, salt marshes, and rocky intertidal zones (Neumann 1976, Williams \& Williams 1998, Goldfinch \& Carman 2000). Twelve genera of marine chironomids and about 50 species were reported by Hashimoto (1976) and Neumann (1976). In North America, 8 chironomid gen- era have been characterized as marine (Colbo 1996), and 5 of these have been found on the Atlantic coast (Clunio, Halocladius, Pontomyia, Tethymyia, and Thalassosmittia; Oliver \& Roussel 1983).

Halocladius variabilis is a marine chironomid with a wide distribution that includes Greenland and the western North Atlantic and Arctic oceans, including the Baltic Sea and White Sea (Hirvenoja 1973, Colbo 1996, Hirvenoja et al. 2006). It was previously reported in eastern Canada by Colbo (1996) from rocky shores in Newfoundland and by Giberson et al. (2001) from salt marshes in Prince Edward Island. The larvae of this species form part of a complex, multi-species, symbiotic community, of which the other primary components are the abundant, intertidal fucoid Ascophyllum nodosum, the obligate, endophytic fungus Mycophycias asco- 
phylli, and the obligate epiphytic red alga Polysiphonia (Vertebrata) lanosa (Garbary \& MacDonald 1995, Garbary \& Deckert 2001, Garbary et al. 2005a,b). Cytological interactions among the algal and fungal components of this community have been described elsewhere (e.g. Garbary \& Deckert 2001, 2005, Deckert \& Garbary 2005, Xu et al. 2008). A fourth member of this community is the brown, cushion-forming, obligate epiphyte Elachista fucicola, which is also abundant on Fucus species. When E. fucicola colonizes A. nodosum, it forms a cushion of tightly interwoven filaments from which arise abundant free filaments up to $2 \mathrm{~cm}$ long. Larvae of $H$. variabilis live among the basal filaments and feed on epiphytes on free filaments of E. fuciola (Garbary et al. 2005b). Although at least 3 other epiphytes are common on A. nodosum (Spongonema tomentosa, Ceramium virgatum, and Pilayella littoralis), at our study site, larvae of $H$. variabilis are found only associated with E. fucicola growing on $A$. nodosum (Garbary et al. 2005b). Elsewhere, Halocladius has been associated with other primary hosts on both $A$. nodusum and Fucus spp. (Johnson \& Scheibling 1987, E. Tarakhovskaya \& D. J. Garbary unpubl.).

There are few studies on the abundance of chironomid larvae on rocky intertidal shores. Colman (1939) reported the maximum densities of Clunio marinus and Thalassomyia frauenfeldi from the mid-zone of a rocky intertidal shore in the UK at 8337 ind. $\mathrm{m}^{-2}$. Neumann (1976) presented maximum larval abundances of 3 species of the intertidal chironomids Paraclunio alaskensis (17500 larvae $\mathrm{m}^{-2}$ ), Saunderia sp. (46500 larvae $\mathrm{m}^{-2}$ ), and C. marinus (58000 larvae $\mathrm{m}^{-2}$ ). Robles \& Cubit (1981) found up to 12000 larvae $\mathrm{m}^{-2}$ for the intertidal chironomids $P$. trilobatus, $P$. alaskensis, and $S$. marinus.

There are even fewer studies that investigate the abundance of chironomid larvae associated with an algal host in the intertidal zone. From his observations at Karo, Japan, Tokunaga (1935) calculated the abundance of Telmatogeton japonicus associated with the intertidal green alga Ulva pertusa and found 1470 to 1660 ind. $\mathrm{m}^{-2}$ of rock surface. Colbo (1996) provides qualitative observations on the diversity of subfamilies and species of chironomid larvae found in the filamentous alga Pilayella littoralis in a rocky intertidal habitat in Newfoundland.

The length of the life cycle varies widely among chironomid species; reported numbers of generations $\mathrm{yr}^{-1}$ vary from 0.14 (i.e. 1 generation in 7 yr) to $>5$ (Tokeshi 1995) and occasionally higher. Benke (1998) reports generation times of $<2 \mathrm{wk}$ ( $>25$ generations $\mathrm{yr}^{-1}$ ) for various chironomids in the Ogeechee River, USA. Tokeshi (1995) reports that of 125 chironomid species, $33 \%$ were univoltine, $44 \%$ bivoltine, and $18 \%$ multivoltine. Several genera of the subfamily Orthocla- diinae, which includes Halocladius, are multivoltine (Tokeshi 1995). Four or more generations $\mathrm{yr}^{-1}$ have been reported in riverine species in this subfamily, including Cricotopus fuscus, Thienemanniella majuscula, Eukiefferiella, Rheocricotopus fuscipes, and Orthocladius frigidus (Tokeshi 1995). There are no reports on voltinism in Halocladius.

Breeding experiments by Neumann (1976) are the only studies on the duration of the life cycle of any intertidal chironomids. The larval stage lasted $49 \mathrm{~d}$ in Clunio tsushimensis and $57 \mathrm{~d}$ in C. marinus. Growth rates and development times depend strongly on temperature (Neumann 1976, Tokeshi 1995). Average surface temperatures in Nova Scotia typically remain around $0^{\circ} \mathrm{C}$ from January to April and exceed $10^{\circ} \mathrm{C}$ for only a few months in summer and early fall. A relatively long life cycle may therefore be anticipated for Halocladius variabilis, but this has not been investigated.

The general ecology of the mesoherbivore-epiphytehost interaction between Halocladius variabilis larvae and the epiphytic brown alga Elachista fucicola on Ascophyllum nodosum has been described earlier (Garbary et al. 2005b). The relationship is evidently mutualistic, in that both E. fucicola and $H$. variabilis benefit from the presence of the other species. The alga benefits by having the insect remove epiphytes from its photosynthetic filaments and provide fecal nitrogen to the basal system; the insect benefits by having a cryptic microhabitat that provides an abundant food source in the form of the epiphytic diatoms on its host. The purpose of the present study was to estimate the population density and annual production of this unusual insect.

\section{MATERIALS AND METHODS}

Study site. The population biology of Halocladius variabilis was studied at Drum Head, on the Atlantic coast of Nova Scotia, Canada ( $45^{\circ} 08^{\prime} 44^{\prime \prime}$ N, 61 $36^{\circ} 02^{\prime \prime}$ W) (Fig. 1). The site is a fully saline, moderately exposed rocky shore that is slightly protected from wave exposure by offshore islands. The substratum consists of a large boulder field on a gently sloping shore with an intertidal zone of 10 to $30 \mathrm{~m}$. This area is dominated in the mid-intertidal zone by extensive populations of Ascophyllum nodosum that cover over $50 \%$ of the substratum at low tide (Fig. 2). Tidal amplitude is $\sim 2 \mathrm{~m}$. The low intertidal zone and occasional shallow pools have extensive populations of Chondrus crispus. The site was initially visited on 22 May 2001 as part of a geographic survey of $H$. variabilis and then selected as the primary study site based on the occurrence of the insect and proximity to Antigonish. 


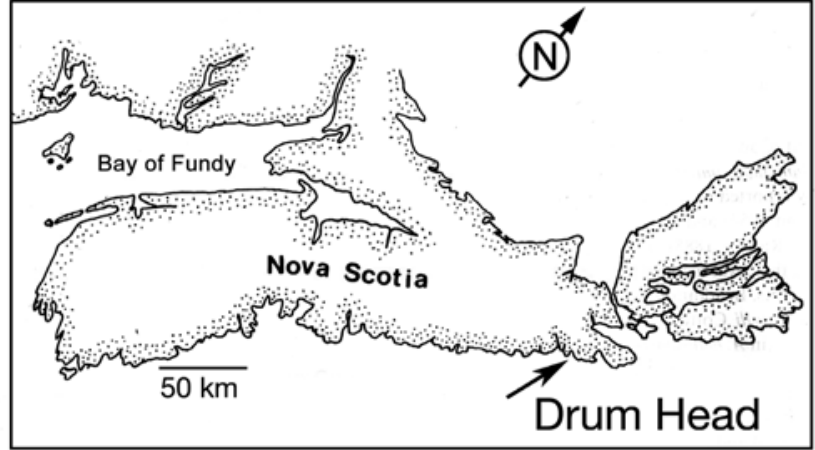

Fig. 1. Location of the study site at Drum Head, Nova Scotia, Canada

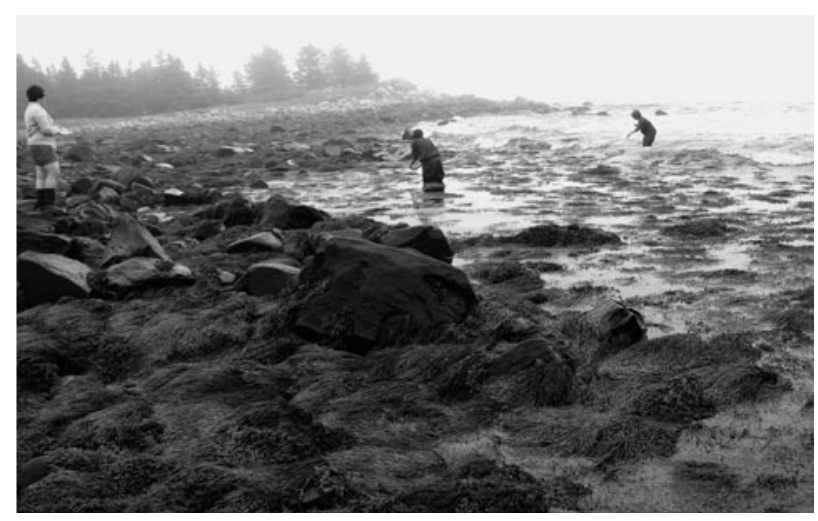

Fig. 2. Intertidal zone at Drum Head at mid-tide. All 3 people are in the Ascophyllum nodosum zone. Note extensive horizontal distribution of $A$. nodosum and dense cover of substratum by $A$. nodosum in foreground

Population estimation of Halocladius variabilis. Estimating the population size of $H$. variabilis was a 3-step procedure that required (1) determining the density of fronds of Ascophyllum nodosum in the intertidal zone, (2) quantifying the abundance of Elachista fucicola on each A. nodosum frond and (3) quantifying the abundance of $H$. variabilis in each thallus of $E$. fucicola. Counts of algae and chironomids were done at roughly biweekly intervals from early June to August 2001, and monthly between September and November, for a total of 10 counts (see Table 1). Preliminary counts were also made on 1 June.

Step 1 above was done by estimating the density of Ascophyllum nodosum fronds $>20 \mathrm{~cm}$ long in each of six $20 \times 40 \mathrm{~cm}$ quadrats (long axis perpendicular to the shore) placed at each of 2 tidal heights (total 12 quadrats). Short fronds were omitted because of the low density of epiphytes on them. The 2 sets of quadrats were placed about $1 / 4$ and $3 / 4$ of the horizontal distance through the A. nodosum zone. At each tide level, successive quadrats were separated by $20 \mathrm{~cm}$. Because vegetation within quadrats was destructively sampled, quadrat locations were staggered from one collection time to another to minimize resampling (Table 1). In each quadrat the number of fronds $>20 \mathrm{~cm}$ length was counted and 5 fronds were haphazardly sampled. Unbiased sampling was possible because the density of fronds made it difficult to see the full length of individual fronds. When fronds $<20 \mathrm{~cm}$ were accidentally chosen, they were discarded. The fronds from each quadrat were placed in separate labelled bags. On return to the laboratory, fronds were refrigerated at $4^{\circ} \mathrm{C}$ until processing was completed.

The length of each Ascophyllum nodosum frond was measured and the number of clumps of Elachista fucicola on it was counted. Five thalli of E. fucicola were haphazardly removed from 2 fronds from each quadrat (total 10 thalli) and examined under a dissecting microscope. The thallus was teased apart with fine forceps, and each $H$. variabilis larva was removed and its length measured. Following the removal of all larvae, the thallus was air-dried for 24 to $48 \mathrm{~h}$ at room temperature and then weighed.

Estimates of the number of larvae per $\mathrm{m}^{2}$ of shore took into account the distributions of the 3 organisms counted. The distribution of Ascophyllum nodosum among quadrats is approximately normal, but the distribution of Elachista fucicola thalli on a single frond or among fronds is non-normal (left-skewed) and more closely follows a log-normal distribution. The distribution of Halocladius variabilis larvae is log-normal among $A$. nodosum fronds and among quadrats. The density of $A$. nodosum fronds per quadrat (each

Table 1. Ascophyllum nodosum. Changes in location of sites sampled at Drum Head from June to November 2001. Six $20 \times$ $40 \mathrm{~cm}$ quadrats were placed at each of 2 tidal heights (about $1 / 4$ and $3 / 4$ of the horizontal distance through the A. nodosum zone) on each date. Distances and tidal heights were not determined (-) during preliminary sampling on 1 June, nor on 28 June due to inclement weather. Reference point on the shore was a large piece of scrap metal above the upper limit of the A. nodosum zone

\begin{tabular}{|lcccc|}
\hline \multirow{2}{*}{ Sampling date } & \multicolumn{2}{c|}{$\begin{array}{l}\text { Distance from } \\
\text { reference }(\mathrm{m})\end{array}$} & \multicolumn{2}{c|}{$\begin{array}{c}\text { Height above sea } \\
\text { level }(\mathrm{cm})\end{array}$} \\
& Upper & Lower & Upper & Lower \\
\hline 1 June & - & - & - & - \\
13 June & 3.0 & 15.0 & 57.1 & 45.0 \\
28 June & - & - & - & - \\
10 July & 4.0 & 12.0 & 61.5 & 53.2 \\
19 July & 5.4 & 13.9 & 40.6 & 32.1 \\
1 August & 6.6 & 9.5 & 49.4 & 46.5 \\
14 August & 3.7 & 9.7 & 57.3 & 51.3 \\
29 August & 2.8 & 8.9 & 57.2 & 51.1 \\
8 September & 3.1 & 11.3 & 53.9 & 45.7 \\
20 October & 3.3 & 11.0 & 30.7 & 23.0 \\
1 November & 5.0 & 11.5 & 24.0 & 17.5 \\
Mean & 4.1 & 11.4 & 48.0 & 40.6 \\
SE & 0.43 & 0.67 & 4.4 & 4.4 \\
\hline
\end{tabular}


quadrat was $800 \mathrm{~cm}^{2}$ ) was converted to density $\mathrm{m}^{-2}$ by multiplying by 12.5 . The density of E. fucicola was calculated by multiplying the counts of thalli on each of 5 fronds by the total number of fronds in that quadrat, for a total of 60 independent estimates of thallus density on each date, and multiplying the results by 12.5. The density of $H$. variabilis was estimated by multiplying each of the 2 counts of larvae per E. fucicola thallus by the calculated number of thalli $\mathrm{m}^{-2}$ estimated for that A. nodosum frond as given above. For the remaining 3 fronds in each quadrat, the density of $H$. variabilis on the first 2 fronds (the best estimate for that quadrat) was used as the larval count for the calculations; $H$. variabilis densities were therefore based on 60 estimates for each sampling date. This procedure preserves the distributions of all the species involved in each calculation in the final estimate. Population density estimates with normal distributions are presented as mean $\pm \mathrm{SE}$; medians and 25th and 75th percentiles of the range are used for non-normal distributions.

Most population estimates displayed an apparently unimodal or bimodal pattern of densities across the sampling season (see 'Results'). To establish whether these patterns were significant, in the face of substantial variability, piece-wise linear regression was used (Neter et al. 1983). Piece-wise regression simultaneously defines 2 straight lines with different slopes, such as an increase and a decrease in a population, connected at a hinge point. The piece-wise regression equation has the form

$$
Y=b_{0}+b_{1} X_{1}-b_{2}\left(X_{1}-b_{3}\right)\left(X_{1}>b_{3}\right)
$$

where $Y$ is the population estimate, $b_{0}$ is the intercept, $b_{1}$ and $b_{2}$ are the first and second slope components, $b_{3}$ is the hinge point, and the phrase $\left(X_{1}>b_{3}\right)$ has a conditional value of 1 or 0 . For population estimates before the hinge point on the $x$-axis (time), the equation defines a simple linear function with slope $b_{1}$. Beyond the hinge point, the equation simplifies to a second line with slope $b_{1}-b_{2}$ (Neter et al. 1983). Equations were fitted by repeated least-squares regression, with different values of $b_{3}$ supplied for each iteration (Taylor et al. 1991). Because the regression was used only to establish the significance of temporal trends, the values of the estimates and the fidelity of a linear model are of less interest than the overall significance of the regression. Where comparisons between 2 adjacent, individual dates were required, a $t$-test was used.

Life history. To determine the life history stage of Halocladius variabilis at Drum Head, lengths of individual larvae were measured from every collection trip from 1 June to 17 November 2001. Larvae collected at nearby Tor Bay on 22 May were also included. About 100 larvae were measured from each collection (range: 31 to 177). Cohort growth was inferred from changes in histograms of larval length from one sampling time to the next. Since every collection yielded varying numbers of larvae, the frequency histograms were based on percent frequency of 12 size classes measured in $1 \mathrm{~mm}$ increments from 0 to $12 \mathrm{~mm}$. Mean larval length for each collection trip was also calculated based on these values.

Productivity. Productivity of Halocladius variabilis was estimated using the size-frequency method of Benke \& Huryn (2006). The size distribution of larvae collected from Ascophyllum nodosum fronds was divided into six $2 \mathrm{~mm}$ categories from $0-2 \mathrm{~mm}$ to 10-12 mm. No larvae were $>12 \mathrm{~mm}$. Dry mass in $\mathrm{mg}$ of each individual larva was estimated according to the length-mass equation:

$$
\text { Mass }=0.0018 \times \text { Length }^{2.617}
$$

taken from a summary of many such equations for various insect groups compiled by Benke et al. (1999). The mean equation for Chironomidae was selected rather than that for the subfamily Orthocladiinae because only 1 equation for the Orthocladiinae, based on 39 animals, is available. The values of the constants vary over a narrow range within the Chironomidae (Benke et al. 1999).

The mean individual mass was calculated for all larvae in each size class on each date. That value was then multiplied by the mean density (number $\mathrm{m}^{-2}$ ) to render the estimated biomass for that date and size class. To calculate productivity, the average population density and biomass in each size class over the entire year was taken as the means of the densities and biomasses on each of the 12 sampling dates. From these data, the loss of individuals and gain in mean size over the life of an average cohort of larvae was calculated according to the procedure in Benke \& Huryn (2006). The production to biomass $(P: B)$ ratio was calculated as the sum of the production from all size classes of the average cohort divided by the sum of the mean biomass in all size classes. This calculation estimates cohort production assuming a 1 yr life span. If Halocladius variabilis is bivoltine, the above estimate must be doubled to estimate annual production.

\section{RESULTS}

\section{Abundance of Ascophyllum nodosum and Elachista fucicola}

Between June and November, Ascophyllum nodosum density ranged from 356 to 769 fronds $\mathrm{m}^{-2}$ with a mean of $546 \pm 46$ fronds $\mathrm{m}^{-2}$. Frond density was relatively low during the early summer, reached a peak in July and August and then declined to spring levels during the fall 
(Fig. 3A). Although piece-wise regression recognized an increase from a mean of $\sim 400$ fronds $\mathrm{m}^{-2}$ in early July to $\sim 800 \mathrm{~m}^{-2}$ in early August, with a corresponding decline thereafter $(F=5.39, \mathrm{p}=0.0067, \mathrm{~N}=71)$, it accounts for a small part of the variation $\left(R^{2}=0.14\right)$ compared with the random variation among quadrats. Given that fronds are highly perennial, one might expect frond density to remain relatively stable during the year. The increase in frond density probably reflects late spring growth of smaller fronds into the cohort that we considered, while the subsequent decline reflects removal and breakage of mature fronds below our measurement threshold of $20 \mathrm{~cm}$ because of wave action and herbivory.

Piece-wise regression confirms a 5 -fold increase and decline in density of Elachista fucicola over the sampling period (log-transformed data, $\mathrm{R}^{2}=0.34, F=153.2$, $\mathrm{p}<0.001, \mathrm{~N}=597)$. An overwintering population of $<5000 \mathrm{~m}^{-2}$ in June reproduced to produce a new cohort that reached 20000 thalli $\mathrm{m}^{-2}$ by mid-July (Fig. 3B). Density then declined through the remainder of the year; median densities intercepted 0 by September, although some fronds retained substantial populations. The plants in November probably represent a remnant population of thalli that overwintered along with their Halocladius variabilis larvae. The peak in E. fucicola density corresponds with a peak in its biomass (data not shown) and the 2 variables are closely correlated.
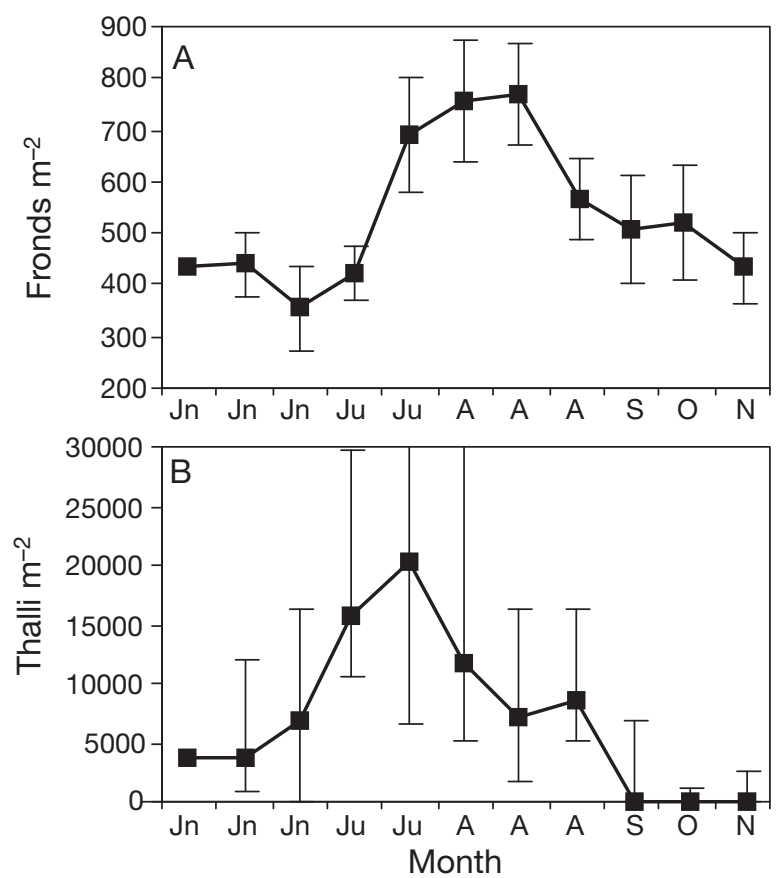

Fig. 3. Ascophyllum nodosum and Elachista fucicola. Changes in (A) mean $( \pm \mathrm{SE})$ density of fronds of A. nodosum and (B) median density of thalli of E. fucicola (error bars indicate 25th and 75th percentiles). Jn: June; Ju: July. See Table 1 for exact sampling dates

\section{Abundance of Halocladius variabilis}

The mean number of Halocladius variabilis larvae per Elachista fucicola thallus varied from $0.5 \pm 0.1$ larva thallus ${ }^{-1}$ in mid-June to $3.9 \pm 0.5$ larvae thallus $^{-1}$ in mid-July (Fig. 4A). The highest number occurred in the 14 August collection, when 17 larvae were observed in a single E. fucicola thallus. Fig. 4A shows 2 peaks in number of larvae thallus ${ }^{-1}$, the first occurring on 10 July $\left(3.9 \pm 0.5\right.$ larvae thallus $\left.{ }^{-1}\right)$ and the second on 29 August $\left(3.5 \pm 0.4\right.$ larvae thallus $\left.^{-1}\right)$. From the peak in August, there was a steady decrease down to $0.8 \pm 0.1$ larva thallus ${ }^{-1}$ by October. The increase and decline around the first peak is highly significant $\left(\mathrm{R}^{2}=\right.$ $0.27, F=36.1, \mathrm{p}<0.001, \mathrm{~N}=198)$ as is that around the second peak $\left(R^{2}=0.30, F=48.5, p<0.001, N=230\right)$.
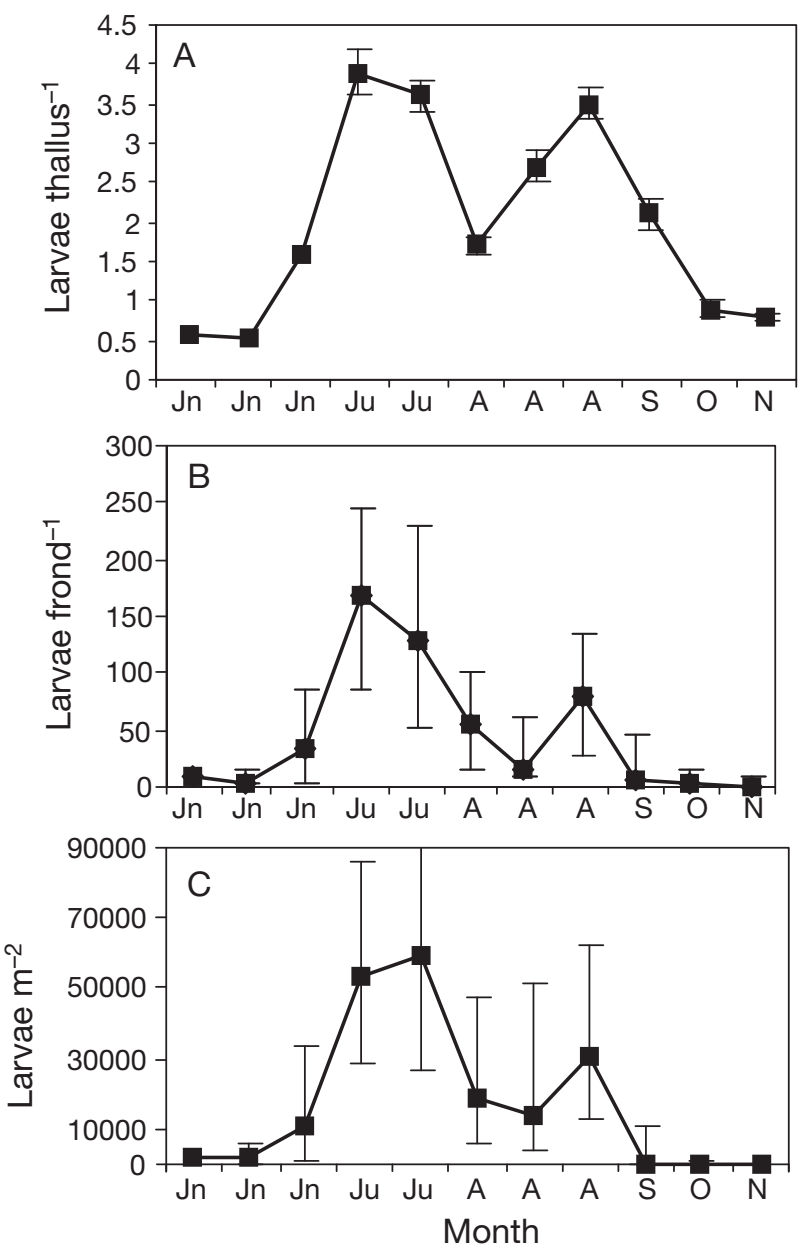

Fig. 4. Halocladius variabilis. Population estimates (median with error bars indicating 25th and 75th percentiles) of the marine midge. (A) Number of larvae per thallus of E. fucicola growing on A. nodosum fronds; modified from Garbary et al. (2005b). (B) Number of larvae per frond of A. nodosum. (C) Density of larvae per $\mathrm{m}^{2}$ of substratum. Note: where error bars are not apparent, they are included within the size of the square. Jn: June; Ju: July. See Table 1 for exact sampling dates 


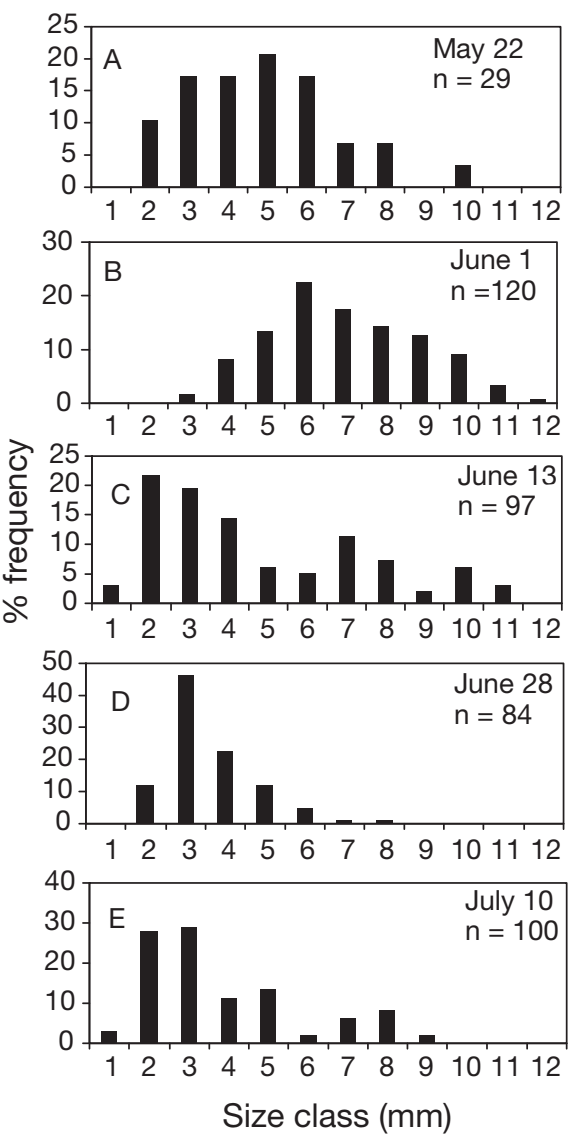

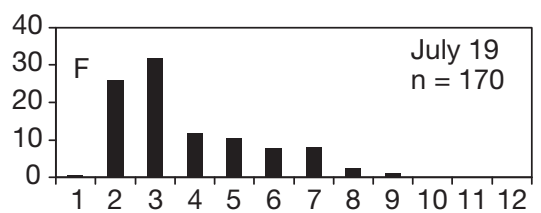
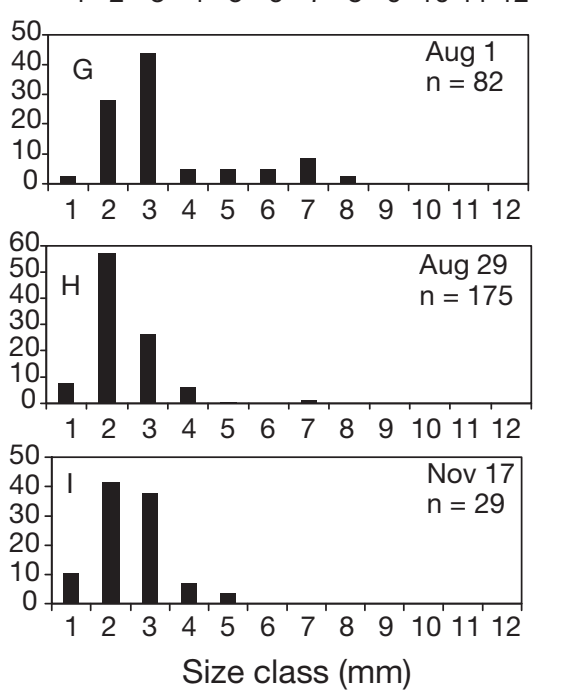

Fig. 5. Halocladius variabilis. Size distributions of larvae from May to November transformed data, $\mathrm{R}^{2}=0.26, F=38.3, \mathrm{p}<$ $0.001, \mathrm{~N}=221$ ). However, the decline is again interrupted by a smaller, but significant increase $(t=2.81, \mathrm{p}=0.0036, \mathrm{df}=$ 45) between 14 and 29 August, over which period the median density of $H$. variabilis increased from 16 to 79 frond $^{-1}$ (Fig. 4B). The peak density frond $^{-1}$ (10 July) appears to occur earlier than that for density $\mathrm{m}^{-2}$ of seashore (19 July), but the difference between these 2 dates is not significant.

\section{Life history}

More than 1 generation $\mathrm{yr}^{-1}$ of Halocladius variabilis is demonstrated by the changing frequencies of larval length (Fig. 5). The overwintering cohort was evident during the sampling dates 22 May, 1 June and 13 June (Fig. 5A-C), when 72.3, 98.4 and $55.7 \%$ respectively of the larvae were $>3 \mathrm{~mm}$ in length. The shift toward larger sizes between 22 May and 1 June, followed by re-appearance of very small larvae on 13 June, is consistent with the development and emergence of an overwintering cohort.

From July to September, $83 \%$ of over 1500 E. fucicola thalli had $\geq 1 H$. variabilis larva. By October and November, only $40 \%$ of the E. fucicola thalli had $\geq 1$ H. variabilis larva.

Densities of Halocladius variabilis per $\mathrm{m}^{2}$ of substratum and per frond of Ascophyllum nodosum followed similar patterns through time (Fig. 4B,C). Densities on an aerial basis increased by a factor of 30 from a median of $1300 \mathrm{~m}^{-2}$ on 13 June to $59500 \mathrm{~m}^{-2}$ on 19 July. The upper 75th percentile density on 19 July approached $150000 \mathrm{~m}^{-2}$. Densities declined steeply thereafter, to a median of 0 by 8 September. By 17 November the upper 75 th percentile of population density was only $105 \mathrm{~m}^{-2}$. Based on all observations, the increase and decline across the sampling season is highly significant (logtransformed data, $\mathrm{R}^{2}=0.40, F=195.4, \mathrm{p}<0.001, \mathrm{~N}=597$ ) according to piece-wise linear regression. However, the decline is interrupted by a smaller, but significant increase (log-transformed data, $t=2.88, \mathrm{p}=0.0024, \mathrm{df}=$ 114) between 14 and 29 August. Median H. variabilis density reached $31000 \mathrm{~m}^{-2}$ on 29 August compared with $13000 \mathrm{~m}^{-2} 2$ wk earlier (Fig. 4C). Similarly, densities per frond of $A$. nodosum increased significantly from a median of 4.1 on 13 June to 169.5 on 10 July, then declined steeply to a median of 0 by 17 November (log-
In June and July (Fig. 5D-F), uniformly $50 \%$ of the larvae were $<3 \mathrm{~mm}$ length. By 28 June, almost the entire population of larvae were $<6 \mathrm{~mm}$ long, indicating a young summer cohort. On 10 and 19 July, and to a lesser extent on 1 August (Fig. 5G), small numbers of larger larvae appeared, but the bulk of the population remained very small. This pattern suggests growth of larvae from the overwintering cohort combined with new larvae developing from eggs laid over the summer. If there were only 1 cohort, a steady increase in mean size over the summer would be expected. By the end of August (Fig. 5H), the summer generation had almost entirely emerged and small larvae again dominated the distribution. All the larvae collected in November were $<5 \mathrm{~mm}$ long (Fig. 5I); presumably these animals would have emerged the following spring. Hence, size distributions suggest a long, overwintering cohort which emerges in June, followed by $\geq 1$ summer generation. Bivoltinism is also suggested by the 2 peaks of larval densities per thallus of Elachista fucicola, in July and August (Fig. 4A), reflected as smaller second peaks of density per $\mathrm{m}^{2}$ and per Ascophyllum nodosum frond (Fig. 4B,C) and by the temporal distribution of the few pupae and egg masses observed (Garbary et al. 2005b). 


\section{Productivity}

The biomass of Halocladius variabilis larvae ranged from $0.30 \mathrm{~g} \mathrm{~m}^{-2}$ on 17 November to $139.1 \mathrm{~g} \mathrm{~m}^{-2}$ on 10 July (Fig. 6). There was also a spike in larval biomass on 1 June at $78 \mathrm{~g} \mathrm{~m}^{-2}$. The onset of August heralded the start of a decrease in biomass that continued through to November. Biomass was low on 13 and 28 June, indicating the emergence of adults and the start of a new generation. Based on the size-frequency method, the cohort production of $H$. variabilis larvae was $130 \mathrm{~g}$ $\mathrm{m}^{-2} \mathrm{yr}^{-1}$ (Table 2$)$. The cohort production/biomass $(P: B)$ ratio of 4.35 is close to the theoretically expected value of 5 (Benke \& Huryn 2006). If $H$. variabilis produces $\geq 2$ generations $\mathrm{yr}^{-1}$, as seems likely, then annual production of this insect would be $\geq 260 \mathrm{~g} \mathrm{~m}^{-2} \mathrm{yr}^{-1}$ and the

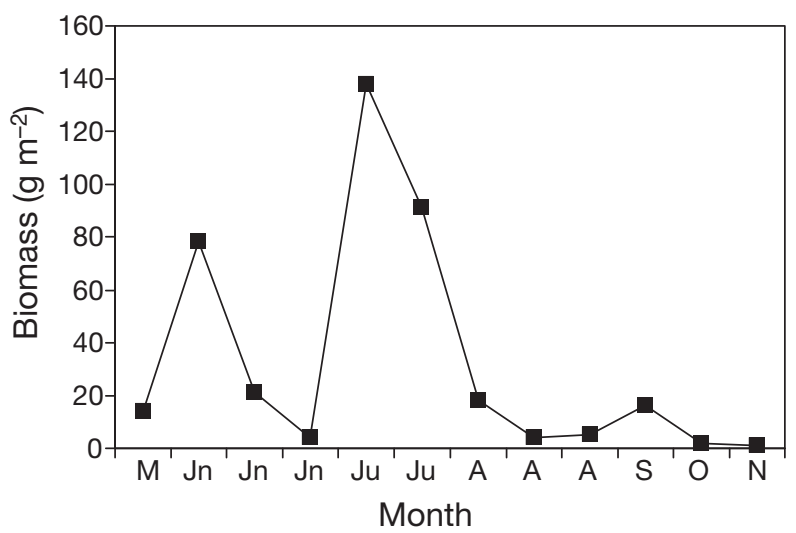

Fig. 6. Halocladius variabilis. Biomass of larvae from May to November. Jn: June; Ju: July

Table 2. Halocladius variabilis. Mean biomass and estimated annual production using the size-frequency method (Benke \& Huryn 2006). Numbers in bold at the bottom of columns are totals. Cohort $P: B=$ production/total biomass. No. lost: difference in density between size class $X$ and size class $X+1$. Mass at loss: mean of individual masses in size class $X$ and size class $X+1$. Biomass lost between size classes is multiplied by the number of size classes, based on the assumption that the size-frequency method estimates an average cohort, of which there are as many per year as the number of size classes. See Benke \& Huryn (2006) for rationale

\begin{tabular}{|c|c|c|c|c|c|c|c|}
\hline $\begin{array}{l}\text { Size } \\
\text { class } \\
(\mathrm{mm})\end{array}$ & $\begin{array}{l}\text { Density } \\
\left(\text { no. } \mathrm{m}^{-2} \text { ) }\right.\end{array}$ & $\begin{array}{l}\text { Individual } \\
\text { mass } \\
(\mathrm{mg})\end{array}$ & $\begin{array}{l}\text { Biomass } \\
\left(\mathrm{mg} \mathrm{m}^{-2}\right)\end{array}$ & $\begin{array}{l}\text { No. lost } \\
\left(\mathrm{m}^{-2}\right)\end{array}$ & $\begin{array}{l}\text { Mass at } \\
\text { loss } \\
(\mathrm{mg})\end{array}$ & $\begin{array}{l}\text { Biomass } \\
\text { lost } \\
\left(\mathrm{mg} \mathrm{m}^{-2}\right)\end{array}$ & $\begin{array}{l}\text { Times no. } \\
\text { of size } \\
\text { classes (mg) }\end{array}$ \\
\hline $0-2$ & 16628.1 & 0.0056 & 93.5 & & & & \\
\hline $2-4$ & 30710.8 & 0.0254 & 779.1 & $-14082.7^{a}$ & 0.015 & -218.2 & $-1309.4^{\mathrm{b}}$ \\
\hline $4-6$ & 41036.2 & 0.110 & 4529.4 & -10325.4 & 0.068 & -700.8 & $-4204.8^{\mathrm{b}}$ \\
\hline $6-8$ & 35462.3 & 0.284 & 10068.8 & 5573.9 & 0.197 & 1098.9 & 6593.5 \\
\hline $8-10$ & 21384.9 & 0.508 & 10853.2 & 14077.4 & 0.396 & 5570.8 & 33424.6 \\
\hline \multirow[t]{2}{*}{$10-12$} & 4228.8 & 0.830 & 3510.5 & $\begin{array}{r}17156.1 \\
4228.8\end{array}$ & $\begin{array}{l}0.669 \\
0.830\end{array}$ & $\begin{array}{r}11474.5 \\
3510.5\end{array}$ & $\begin{array}{l}68847.2 \\
21063.0\end{array}$ \\
\hline & & $\begin{array}{l}\text { Total } \\
\text { Cohort } F\end{array}$ & $\begin{array}{l}29834.5 \\
P: B 3.54\end{array}$ & & & Production & 129928.3 \\
\hline
\end{tabular}

annual $P: B$ ratio would be 8.7 . These values are more consistent with the peak calculated biomass values for June and July (i.e. 78 and $139 \mathrm{~g} \mathrm{~m}^{-2}$ ) and recognize that our production estimate of $130 \mathrm{~g} \mathrm{~m}^{-2} \mathrm{yr}^{-1}$ is a conservative determination.

\section{DISCUSSION}

Halocladius variabilis is perhaps the most abundant marine insect described to date. Comparable data for other marine and estuarine systems are given in Table 3. The maximum numbers for $H$. variabilis reported here are slightly greater than those for the next highest records (Neumann 1976, Williams \& Williams 1998) and $5 \times$ greater than numbers in rocky intertidal zones in the UK and California (Colman 1939, Robles \& Cubit 1981). In a review of mesoherbivory in marine communities that includes assorted studies of amphipods and isopods, Brawley (1992) cites only a single paper reporting numbers of these animals greater than those for $H$. variabilis. Wildish (1988) reviews the ecology of the superfamily Talitroidea, an amphipod assemblage that can achieve high densities. He cites only 2 studies, Behbehani \& Croker (1982) and Hiwatari \& Kajihara (1984), in which animal densities were comparable with, or greater than, those we report here.

What makes the densities of Halocladius variabilis from Nova Scotia more astounding is that these animals were living in the most prominent part of the intertidal zone, which at our study site extended in a band for over $7 \mathrm{~m}$. Although the horizontal extent of this zone depends upon tidal amplitude and slope of the shore, the 7 to $20 \mathrm{~m}$ width at Drum Head is common on the Atlantic coast of Nova Scotia where Ascophyllum nodosum forms a primary structuring element for the community (e.g. Scrosati \& Heaven 2007). Moreover, although we found $H$. variabilis only in Elachista fucicola growing on A. nodosum, it does not appear that the insect is restricted to the one primary and one ultimate host (Garbary et al. 2005b). In the White Sea, $H$. variabilis was found on several additional brown algae epiphytic on both $A$. nodosum and Fucus vesiculosus (E. Tarakhovskaya \& D. J. Garbary unpubl.). A previous study of the epifaunal communities on intertidal seaweeds in Nova Scotia reports that up to 
Table 3. Densities of chironomids cited from various estuarine and marine ecosystems

\begin{tabular}{|c|c|c|c|}
\hline Habitat & Location & $\begin{array}{l}\text { Density } \\
\left(\mathrm{m}^{-2}\right)\end{array}$ & Source \\
\hline $\begin{array}{l}\text { Rock surface, } \\
\text { intertidal zone }\end{array}$ & Japan & $1470-1660$ & Tokunaga (1935) \\
\hline $\begin{array}{l}\text { Ephemeral algae, } \\
\text { intertidal zone }\end{array}$ & California & 2900 & Robles (1982) \\
\hline Intertidal zone & California & 12000 & Robles \& Cubit (1981) \\
\hline Rocky intertidal zone & UK & 8337 & Colman (1939) \\
\hline $\begin{array}{l}\text { River-dominated } \\
\text { estuary }\end{array}$ & North Wales & 43000 & $\begin{array}{l}\text { Williams \& Williams } \\
\text { (1998) }\end{array}$ \\
\hline Intertidal zone & General & 58000 & Neumann (1976) \\
\hline Rocky intertidal zone & Nova Scotia & 60000 & Present study \\
\hline
\end{tabular}

voltine life history at Drum Head, in which late-instar larvae overwinter and emerge as adults throughout the summer. Temperature is a major factor controlling growth rate and duration of the life cycle in chironomids. Overwintering in the larval stage has been previously observed in intertidal chironomids when temperatures drop below 8 to $10^{\circ} \mathrm{C}$, in Clunio, Paraclunio and Saunderia (Neumann 1976). As the average water temperature in Nova Scotia approaches $-1^{\circ} \mathrm{C}$ between January and April (Edelstein \& McLachlan 1966), overwintering of $H$. variabilis larvae at

4 and $7 \%$ of the total epifaunal abundances associated with $F$. vesiculosus and $A$. nodosum, respectively, were composed of dipteran larvae (Johnson \& Scheibling 1987). Given our observations, these larvae were almost certainly $H$. variabilis. Hence, $H$. variabilis is probably an important component of the rocky shore community over an extensive geographic range.

Halocladius variabilis is also among the most productive intertidal invertebrates known. Our estimate of $130 \mathrm{~g} \mathrm{~m}^{-2} \mathrm{yr}^{-1}$ is extraordinary compared with chironomids from other habitats, and as great as that of any non-calcified consumer on the seashore. Although we suspect that total crustacean production may be greater (see Johnson \& Scheibling 1987), this is a mixture of many species rather than the single species of $H$. variabilis reported here. Tokeshi (1995) classifies production values for Chironomidae as extremely high if they exceed $32 \mathrm{~g} \mathrm{~m}^{-2} \mathrm{yr}^{-1}$, roughly $1 / 4$ of our estimate. As with $H$. variabilis, such high productivities generally arise in special habitats dominated by a single species. The greatest chironomid production previously reported is for a population of Glyptotendipes barpipes inhabiting sewage lagoons in Oregon, where annual production was estimated to be $92 \mathrm{~g} \mathrm{~m}^{-2} \mathrm{yr}^{-1}$ (Kimerle \& Anderson 1971). Benke (1998) reported annual production by a chironomid community in a southern US stream, dominated by Rheotanytarsus, Rheocricotopus and Polypedilum, of up to $26.8 \mathrm{~g} \mathrm{~m}^{-2} \mathrm{yr}^{-1}$. With respect to species of Orthocladiinae, annual production has been cited to range between 0.001 and $100 \mathrm{~g} \mathrm{~m}^{-2} \mathrm{yr}^{-1}$ (Tokeshi 1995). Relatively high production, exceeding $1 \mathrm{~g} \mathrm{~m}^{-2} \mathrm{yr}^{-1}$, has been reported mainly for lotic midge genera such as Tvetenia, Cricotopus, Eukiefferiella and Orthocladius. The highest value of annual production reported to date for orthoclads refers to Chaetocladius melaleucus in an artificial recirculating stream in England $\left(25 \mathrm{~g} \mathrm{~m}^{-2}\right.$ $\mathrm{yr}^{-1}$; Ladle et al. 1985). Productivity of $H$. variabilis has not been previously reported.

This uniquely high productivity estimate for Halocladius variabilis is based on the assumption of a uni-
Drum Head is to be expected. On the other hand, the double peaks of $H$. variabilis density at every level of sampling, first in July and again in August, strongly suggest that there is a second summer generation of $H$. variabilis at Drum Head that develops rapidly when the water is warmer. Continual emergence and egg-laying throughout the brief summer would account for the unvarying proportions of both small and medium-sized larvae in July and August. Bivoltinism would also be more consistent with other intertidal chironomids of the subfamily Orthocladiinae, among which the majority of species are multivoltine (Tokeshi 1995). If $H$. variabilis is bivoltine or multivoltine, estimated annual production would be even greater, approaching or exceeding $260 \mathrm{~g} \mathrm{~m}^{-2} \mathrm{yr}^{-1}$. This value is almost $3 \times$ greater than any previous report for a single species of chironomid, and 1 to 2 orders of magnitude greater than typical values for productive species. It is also more consistent with the biomass estimates calculated during the present study.

Using the conversion constant of 21 proposed by Waters (1977), our conservative production estimate of $130 \mathrm{~g} \mathrm{~m}^{-2} \mathrm{yr}^{-1}$ converts into $2730 \mathrm{~kJ} \mathrm{~m}^{-2} \mathrm{yr}^{-1}$. Converting that number into the $\log _{10}$ units used by Cusson \& Bourget (2005) for comparison of marine benthic macroinvertebrates produces the value of 3.436. This value for Halocladius variabilis is 2 to $3 \times$ larger than mean values given by Cusson \& Bourget (2005) for comparable taxonomic groups of Arthropoda (1.30), the functional guild of grazers (1.64) and substratum type of algae (1.10). Hence, estimated production by $H$. variabilis is 100 to $1000 \times$ larger than that of comparable groups of species in benthic habitats.

Halocladius variabilis is unique in another respect, in that the exceptional productivity is sustained by a very large population and a relatively small $P: B$ ratio. This ratio is a weighted mean of biomass growth rates of all individuals in the population (Benke \& Huryn 2006), and is essentially an indicator of biomass turnover. Most chironomids, and indeed most organisms, which exhibit rapid production do so on the basis of very high 
biomass turnover. For example, Benke (1998) presents data from 7 studies on chironomid production in freshwater rivers, illustrating $P: B$ ratios ranging from 30 to $>200$. The $P: B$ ratio for intertidal Halocladius variabilis (4.35 or 8.70 depending on voltinism) is entirely ordinary (Benke \& Huryn 2006) and brackets the common range for Orthocladiinae (6.0 to 8.0; Tokeshi 1995). However, the higher $P: B$ estimate for $H$. variabilis is well above mean $P: B$ values for marine benthic macroinvertebrates given by Cusson \& Bourget (2005).

The high productivity of Halocladius variabilis therefore rests on its high population density. This density, in turn, is a function of the 3-dimensional habitat created by Ascophyllum nodosum The seaweed fronds create a much larger surface area for colonization by Elachista fucicola, and hence $H$. variabilis, than would be possible if the chironomid were living directly on the intertidal rocks. When this large volume of habitat is projected onto a 2-dimensional surface for the calculation of aerial production rates, the observed high values result. A similar situation is reported for southern US rivers (Benke et al. 1984, Benke 1998) in which chironomid production is strongly concentrated on fallen wood (snags) rather than the soft river bottom. But because snags do not create multiple layers of habitat as intertidal fucoids do, production estimates per area of river bottom are less than per area of snag.

The productivity of Halocladius variabilis has not previously been accounted for in models of intertidal food webs. Predators of $H$. variabilis have not been determined; however, given the size and microhabitat of the chironomid, they are a likely food source for the same consumers that eat amphipods. In North Carolina, Duffy \& Hay (2000) found that dominance of the seaweed community by phaeophytes was facilitated by omnivorous fishes that feed not only on the red algae and green algae, but also on the herbivorous amphipods which graze on the brown seaweed. It would be of interest to resolve the food webs of the intertidal zone of Atlantic Nova Scotia, to determine the importance of $H$. variabilis to community production.

The productivity of Halocladius variabilis raises an important issue regarding the harvesting of Ascophyllum nodosum in southwestern Nova Scotia (Sharp 1986). Elachista fucicola (the host of $H$. variabilis) is more abundant in the upper portions of its own $A$. nodosum host. Consequently, harvesting of A. nodosum by cutting fronds removes the bulk of the E. fucicola and $H$. variabilis from the habitat. This can only have negative implications for the consumers of $H$. variabilis The complexity of the A. nodosum symbiotic community (Garbary \& Deckert 2001, Deckert \& Garbary 2005, Garbary et al. 2005b) suggests that diverse studies of this community are required before harvesting can be considered benign.

\section{CONCLUSIONS}

Our study has demonstrated that a cryptic and littlestudied marine insect, Halocladius variabilis, is one of the most abundant such chironomids yet discovered, and the most productive. On an aerial basis, $H$. variabilis appears to be by far the most productive chironomid known from any habitat, and quite possibly the most productive single species of non-calcified consumer on the seashore. Given the known range of $H$. variabilis and the abundance of its host fucoids, it is likely that $H$. variabilis is widespread along the Atlantic seaboard of North America as well as in other parts of the northern hemisphere. That this extraordinary species could be overlooked for so long is a consequence of its cryptic habitat and unusual living arrangements, where indeed we only discovered them by accident. The Elachista fucicola thalli among which $H$. variabilis larvae live would appear to provide effective defense against predators. Nevertheless, it seems unlikely that no marine predators would be adapted to take advantage of such an abundant food source. Further studies to determine the contribution of $H$. variabilis to intertidal food webs are clearly needed.

In a key study on chemical defenses of algae and amphipod herbivory, Hay et al. (1987) poses the rhetorical question: Are amphipods insect equivalents? In their concluding sentence they state 'it appears that some species of small, relatively immobile marine invertebrates may be ecologically similar to terrestrial insects and may play a significant, but largely unstudied, role in the dynamics of marine plant populations.' Based on our studies of Halocladius variabilis, it appears that the role of marine insects themselves has been significantly underemphasized. Marine insects may be as important, both as consumers and as prey, to the ecology of rocky seashores as their terrestrial and freshwater counterparts.

Acknowledgements. S. Fraser, C. Ferguson and H. Mosher provided technical assistance in the laboratory and in the field. P. Cranston provided the original identification of our insect material. This work was supported by grants from the Natural Sciences and Engineering Research Council (NSERC) of Canada and the University Council of Research of St. Francis Xavier University to D.J.G.

\section{LITERATURE CITED}

Behbehani MI, Croker RA (1982) Ecology of beach wrack in northern New England with special reference to Orchestia platensis. Estuar Coast Shelf Sci 15:611-620

Benke AC (1998) Production dynamics of riverine chironomids: extremely high biomass turnover rates of primary consumers. Ecology 79:899-910

Benke AC, Huryn AD (2006) Secondary production of macroinvertebrates. In: Hauer FR, Lamberti GA (eds) Methods 
in stream ecology, 2nd edn. Academic Press, San Diego, CA, p 691-710

Benke AC, van Arsdall TC Jr, Gillespie DM, Parrish FK (1984) Invertebrate productivity in a subtropical blackwater river: the importance of habitat and life history. Ecol Monogr 54:25-63

Benke AC, Huryn AD, Smock AD, Wallace JB (1999) Lengthmass relationships for freshwater macroinvertebrates in North America with particular reference to the southeastern United States. J N Am Benthol Soc 18:308-343

Brawley SH (1992) Mesoherbivores. In: John DM, Hawkins SJ, Price JH (eds) Plant-animal interactions in the marine benthos. Systematics Association special volume no. 46. Clarendon Press, Oxford, p 235-263

Cheng L (1976) Marine insects. North Holland Publishing, Amsterdam

Colbo MH (1996) Chironomidae from marine coastal environments near St. John's, Newfoundland, Canada. Hydrobiologia 318:117-122

Colman J (1939) On the faunas inhabiting intertidal seaweeds. J Mar Biol Assoc UK 24:129-183

Cusson M, Bourget E (2005) Global patterns of macroinvertibrate production in marine benthic habitats. Mar Ecol Prog Ser 297:1-14

Deckert RJ, Garbary DJ (2005) Ascophyllum and its symbionts. VI. Microscopic characterization of the Ascophyllum nodosum (Phaeophyceae), Mycophycias ascophylli (Ascomycetes) symbiotum. Algae 20:225-232

Duffy JE, Hay ME (2000) Strong impacts of grazing amphipods on the organization of a benthic community. Ecol Monogr 70:237-263

Edelstein T, McLachlan JL (1966) Investigations of the marine algae of Nova Scotia. I. Winter flora of the Atlantic coast. Can J Bot 44:1035-1055

Garbary DJ, Deckert R (2001) Three part harmony - Ascophyllum and its symbionts. In: Seckbach J (ed) Symbiosis: processes and model systems. Kluwer Academic Publishers, Dordrecht, p 309-321

Garbary DJ, Deckert R (2005) Ascophyllum and its symbionts. VIII. Interactions among Ascophyllum nodosum (Phaeophyceae), Mycophycias ascophylli (Ascomycetes) and Elachista fucicola (Phaeophyceae). Algae 20:363-368

Garbary DJ, MacDonald KA (1995) The Ascophyllum/Polysiphonia/Mycosphaerella symbiosis. IV. Mutualism in the Ascophyllum/Mycosphaerella interaction. Bot Mar 38: 221-225

Garbary DJ, Deckert R, Hubbard C (2005a) Ascophyllum and its symbionts. VII. Three-way interactions among Ascophyllum nodosum (Phaeophyceae), Mycophycias ascophylli (Ascomycetes) and Vertebrata lanosa (Rhodophyta). Algae 20:353-361

Garbary DJ, Jamieson MM, Fraser SJ, Ferguson CA, Cranston PS (2005b) Ascophyllum (Phaeophyceae) and its symbionts. IX. A novel symbiosis between Halocladius variabilis (Chironomidae, Insecta) and Elachista fucicola (Elachistaceae, Phaeophyceae) from marine rocky shores of Nova Scotia. Symbiosis 40:61-68

Giberson DJ, Bilyj B, Burgess N (2001) Species diversity and emergence patterns of nematocerous flies (Insecta: Diptera) from three coastal salt marshes in Prince Edward Island. Estuaries 24:862-874

Goldfinch AC, Carman KR (2000) Chironomid grazing on benthic microalgae in a Louisiana salt marsh. Estuaries 23:536-547

Hashimoto H (1976) Non-biting midges of marine habitats (Diptera: Chironomidae). In: Cheng L (ed) Marine insects 1. North Holland Publishing, Amsterdam, p 377-414
Hay ME, Duffy JE, Pfister CA (1987) Chemical defense against different marine herbivores: Are amphipods insect equivalents? Ecology 68:1567-1580

Hirvenoja M (1973) Revision der Gattung Cricotopus vander Wulp und ihrer Verwandten (Diptera: Chironomidae). Ann Zool Fenn 101:1-363

Hirvenoja M, Palmén E, Hirvenoja E (2006) The emergence of Halocladius variabilis (Staeger) (Diptera: Chironomidae) in the surroundings of the Tvärmine Biological Station in the northern Baltic Sea. Entomol Fenn 17:87-89

> Hiwatari T, Kajihara T (1984) Population dynamics and life cycle of Hyale barbicornis (Amphipoda, Crustacea) in a blue mussel zone. Mar Ecol Prog Ser 20:177-183

> Johnson SC, Scheibling RE (1987) Structure and dynamics of epifaunal assemblages on intertidal macroalgae Ascophyllum nodosum and Fucus vesiculosus in Nova Scotia, Canada. Mar Ecol Prog Ser 37:209-227

Kimerle RA, Anderson NH (1971) Production and bioenergetic role of the midge Glyptotendipes barbipes (Staeger) in a waste stabilization lagoon. Limnol Oceanogr 16: 646-659

> Ladle M, Cooling DA, Welton S, Bass JAB (1985) Studies on Chironomidae in experimental recirculating stream systems. II. The growth, development and production of a spring generation of Orthocladius calvus. Freshw Biol 15: 243-255

Neter J, Wasserman W, Kuter MJ (1983) Applied linear regression models. R. D. Irwin, Homewood, IL

Neumann D (1976) Adaptations of chironomids to intertidal environments. Annu Rev Entomol 21:387-414

Oliver DR, Roussel ME (1983) The insects and arachnids of Canada: the genera of larval midges of Canada. Biosystematics Research Institute, Ottawa

Robles C (1982) Disturbance and predation in an assemblage of herbivorous Diptera and algae on rocky shores. Oecologia 54:23-31

> Robles CD, Cubit J (1981) Influence of biotic factors in an upper intertidal community: dipteran larvae grazing on algae. Ecology 62:1536-1547

Scrosati R, Heaven C (2007) Spatial gradients in community richness, diversity, and evenness across rocky intertidal environmental stress gradients in eastern Canada. Mar Ecol Prog Ser 342:1-14

Sharp G (1986) Ascophyllum nodosum and its harvesting in eastern Canada. In: Doty MS, Caddy JF, Santelices B (eds) Case studies of seven commercial seaweed resources. FAO Fisheries Technical Papers 281. FAO, Rome, p 4-48

Taylor BR, Prescott CE, Parsons WJF, Parkinson D (1991) Substrate control of litter decomposition in four Rocky Mountain coniferous forests. Can J Bot 69:2242-2250

Tokeshi M (1995) Life cycles and population dynamics. In: Armitage PD, Cranston PA, Pinder, LCV (eds) The Chironomidae: biology and ecology of non-biting midges. Chapman \& Hall, London, p 225-251

Tokunaga M (1935) Chironomidae from Japan IV. On the early stages of a marine midge Telmatogeton japonicus Tokunaga. Philipp J Sci 57:491-511

> Waters TF (1977) Secondary production in inland waters. Adv Ecol Res 10:91-164

Wildish DJ (1988) Ecology and natural history of aquatic Talitroidea. Can J Zool 66:2340-2359

- Williams DD, Williams NE (1998) Aquatic insects in an estuarine environment: densities, distribution and salinity tolerance. Freshw Biol 39:411-421

> Xu H, Deckert RJ, Garbary DJ (2008) Ascophyllum and its symbionts. X. Ultrastructure of the interaction between $A$. nodosum (Phaeophyceae) and Mycophycias ascophylli (Ascomycetes). Botany 86:185-193 